\title{
Locally Advanced Breast Carcinoma
}

National Cancer Institute

\section{Source}

National Cancer Institute. Locally Advanced Breast Carcinoma. NCI Thesaurus. Code C160920.

A breast carcinoma that has spread from its original site of growth to nearby tissues or lymph nodes. 